\title{
Preparation and Characterization of Biocompatible Electrospun Nanofiber Scaffolds
}

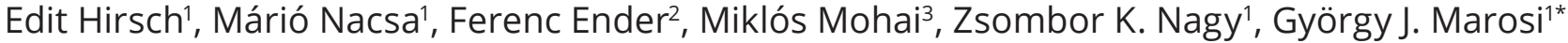 \\ 1 Department of Organic Chemistry and Technology, Faculty of Chemical Technology and Biotechnology, \\ Budapest University of Technology and Economics, H-1111 Budapest, Müegyetem rkp. 3., Hungary \\ 2 Department of Electron Devices, Faculty of Electrical Engineering and Informatics, Budapest University of Technology and \\ Economics, H-1111 Budapest, Múegyetem rkp. 3., Hungary \\ ${ }^{3}$ Research Centre for Natural Sciences, Institute of Materials and Environmental Chemistry, Hungarian Academy of Sciences, \\ H-1519 Budapest, P.O. Box 286, Hungary \\ *Corresponding author, e-mail: gmarosi@mail.bme.hu
}

Received: 15 July 2018, Accepted: 11 September 2018, Published online: 15 October 2018

\begin{abstract}
Nanoscale fibers were prepared for the fabrication of scaffolds by using a strong electrostatic field on the polymer solution. Electrospinning is widely applied for production of drug delivery, tissue engineering, and regenerative medicine systems as well as biosensors and enzyme immobilization. Nanofibers, thanks to their high surface area to volume ratio, can also mimic the extracellular matrix, thus it has been recognized as a suitable technique for the fast fabrication of scaffolds. This article demonstrates the fabrication of several nanofibrous scaffolds from biopolymers such as polycaprolactone, poly(lactic acid), poly(lactide-co-glycolide), poly(lactideco-caprolactone) and poly(hydroxybutyrate-co-hydroxy valerate). The characterization and comparison of the scaffolds were achieved based on the morphology and surface characteristic of the nanofibers. The samples showed hydrophobic characteristic, thus a plasma surface treatment was applied successfully to increase hydrophilicity and the effect of the treatment was evaluated based on the wettability and the change in elemental composition of the surface based on X-ray photoelectron spectroscopy.
\end{abstract}

Keywords

electrospinning, nanomaterials, scaffolds, plasma treatment

\section{Introduction}

Nanotechnology and nano-scale science have been a major part of research in the past few decades. The increasing need for discovering something new on a nano-scale level encouraged scientists to develop nanofibers with controllable pore structure $[1,2]$ for several fields of application such as filtration [3-5], military protective clothing [6-8], nanosensors [9, 10], wound dressings [11-13], drug delivery systems [14-17], enzyme immobilization [18, 19] and scaffolds for tissue engineering [20,21].

Nanofibers can be manufactured with several methods like drawing [22, 23], template synthesis [24, 25], self-assembly [26], phase separation [27, 28] and electrospinning [29-32]. The last one is the most commonly used technique as it has been bursting into the industry in the past few years. It is a quite simple, versatile and reliable method to produce nanofibers from synthetic and natural polymers with diameters in the submicron scale [33].
Electrospinning involves the application of a high electric field to generate nanofibers from a charged polymer solution or melt. Electrospinning parameters can be changed to affect the properties of the nanofibers [14]. These parameters can be the concentration of the polymer solution, polymer molecular weight, conductivity of the polymer solution, voltage, flow rate of the solution, solvent and the distance between the tip and the collector. Additives to the solution can play a major role in controlling the properties of the solution, such as electrical conductivity, dielectric constant, surface tension, and viscosity [34].

It has been determined that nanofibrous structures can create excellent artificial scaffolds for cell cultivation by mimicking the fibrous structure of the extracellular matrix (ECM) as the size of the fibers can be similar to the structure of the ECM. Owing to this advantageous feature, scaffolds have the ability to be seeded with cells and 
engrafted into the human body to stimulate regeneration and regrowth of tissues [31]. These nanofibrous scaffolds have a huge impact on cell migration, embedding, proliferation, and differentiation. The nanofibrous scaffolds can make it possible to grow tissues such as skin $[35,36]$, muscle [37, 38], nerves [39-41], veins [42-44], bone [45, 46], cartilage [47, 48] and ligament [49, 50].

Increased academic interest have shown recently in exploiting the electrospinning technique to produce nanofibers from biocompatible polymers such as polycaprolactone (PCL) [51], poly(lactic acid) (PLA) [52, 53], poly(lactide-co-glycolide) (PLGA) [54, 55], polyurethanes [56], silk fibroin [57], collagen [58, 59], hyaluronic acid [60], cellulose [61] and their blends [62, 63].

In the present work, fabrication and optimization of nanofibrous scaffolds from PCL, PLA, PLGA, poly(lactide-co-caprolactone) (PLC) and poly(hydroxybutyrate-co-valerate) (PHB / HV) biocompatible polymers were achieved using electrospinning method. The scaffold prepared from these biocompatible polymers is a possible choice for the cultivation of cells for different tissue engineering application. Although these polymers are biocompatible, the hydrophobicity of the scaffolds must be reduced in order to promote cell adhesion and migration. Plasma treatment was applied to eliminate this adverse feature. Characterization and comparison of the scaffolds were accomplished based on morphology and surface characteristic.

\section{Experimental}

\subsection{Materials}

The polymers used in the experiment were the following: polycaprolactone (PCL, Perstorp, Capa ${ }^{\mathrm{TM}}$ 6800, $\left.\mathrm{M}_{\mathrm{w}}=80,000\right)$. poly(lactic acid) (PLA, Purasorb ${ }^{\circledR}$ PL 24, $\left.\mathrm{M}_{\mathrm{w}}=339,000\right)$, poly(lactide-co-glycolide) (PLGA, Purasorb $^{\circledR}$ PLG 8523 (85 \% PLA), $\mathrm{M}_{\mathrm{w}}=362,000$ ) and poly(lactide-co-caprolactone) (PLC, Purasorb ${ }^{\circledR} 8516$ $(85 \%$ PLA $\left.), \mathrm{M}_{\mathrm{w}}=221,000\right)$ was purchased from Corbion (Netherlands). Polyhydroxybutyrate (PHB, $\left.M_{w}=973,000\right)$ and poly(hydroxybutyrate-co-hydroxy valerate) (PHB / HV, type L ${ }^{\circledR}, 87 \%$ PHB, $\left.\mathrm{M}_{w}=600,000\right)$ were obtained from Biomer (Germany). Chloroform $\left(\mathrm{CHCl}_{3}\right)$, dichloromethane $\left(\mathrm{CH}_{2} \mathrm{Cl}_{2}\right)$ and $\mathrm{N}, \mathrm{N}$-dimethylformamide (DMF) was obtained from Merck Millipore (USA).

\subsection{Electrospinning process}

To perform electrospinning, an infusion pump (Aitecs SEP-10S Plus syringe pump, Lithuania) was used and high voltage provided by a direct current power supplier (NT-35 High Voltage DC Supply MA2000, Hungary) was applied on an electrostatic spinneret (with an inner diameter of $0.5 \mathrm{~mm}$ ). Nanofibers were collected on conventional aluminum foil immobilized to the grounded collector plate. The high voltage, the collector distance, and the dosing speed were optimized for each solution. All of the experiments were carried out at room temperature.

\subsection{Scanning electron microscopy (SEM)}

The morphology of the nanofibers and the surface of the scaffolds were examined by a JEOL JSM-6380LA scanning electron microscope within the settings of $15 \mathrm{kV}$ acceleration voltage and 10-15 mm sample distance from the microscope in high vacuum. The samples were placed on a copper tool and coated with gold in argon atmosphere in order to avoid electrostatic charging. The experiments must have been performed quickly to prevent the nanofibers from melting.

\subsection{Surface treatment by plasma}

Since the nanofibers are electrostatically charged and quite hydrophobic, surface treatment by plasma is inevitable to increase the hydrophilicity of the scaffolds. The nanofibrous structures were treated with a Femto V1 (Diener Electronic Plasma Surface Technology, Ebhausen, Germany) apparatus at $30 \mathrm{~W}$ in high vacuum. The duration of the plasma treatment was optimized using PCL scaffolds.

\subsection{Water contact angle measurement}

The measurement of the contact angle has been performed using the sessile drop technique. After applying a drop of distilled water $(20 \mu \mathrm{L})$ on the scaffold, a photo was taken of the sample carefully, positioning the contact of the drop in line with the camera's lenses. The contact angles were measured digitally and noted for further use.

\subsection{X-ray photoelectron spectroscopy (XPS)}

XPS tests were performed using a Kratos XSAM 800 (Manchester, UK). The samples were induced by $\mathrm{Mg} \mathrm{K} \alpha$ radiation at $1258.6 \mathrm{eV}$ energy level. The analizator was working in fixed analyzer transmission (FAT) mode with the setting of the transmission window at $40 \mathrm{eV}$ energy level. Small resolution spectra were registered with the step size of $0.5 \mathrm{eV}$ and high-resolution spectra with $0.1 \mathrm{eV}$. Qualitative evaluation of spectra was carried out with Kratos Vision 2 and the quantitative evaluation with XPS MultiQuant computer program. 


\section{Results and discussion}

\subsection{Preparation of nanofibrous scaffolds}

Nanofibrous scaffolds were prepared by electrospinning technique for the purpose of cell cultivation and tissue engineering. In the experiments, the following polymers were used and compared: PCL, PLA, PLGA, PLC and PHB / HV (Fig. 1).

The structure of the nanofibrous system and the diameter of the fibers have a huge impact on the in vitro and in vivo availability of the scaffolds, so the optimization of the electrospinning technology was necessary.

Since the concentrations of the polymer solution have great influence on fiber diameter during electrospinning, several solutions of different concentrations were prepared from PCL, PLA, PHB / HV, PLC and PLGA polymers. The optimal concentrations for each polymer are summarized in Table 1.

The polymers were dissolved in the mixture of halogenated organic solvents and dimethyl-formamide (DMF). DMF has high dielectric constant and is widely used as an addition to form a mixture solvent system to obtain ultrathin fibers with uniform distribution [34].

The electrospinning parameters such as collector distance $(30-35 \mathrm{~cm})$, flow rate $(7-9 \mathrm{~mL} / \mathrm{h})$, and voltage $(25 \mathrm{kV})$ had been optimized for each polymer in order to eliminate the beads and other surficial defects on the scaffolds. While optimizing the parameters, the aluminum<smiles>CCCCCCC(=O)OCC</smiles>

A

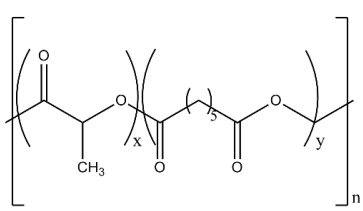

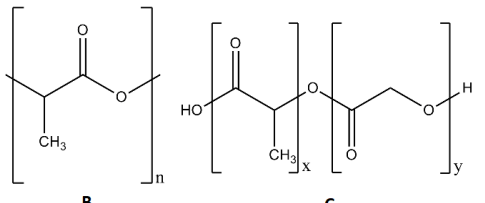

B

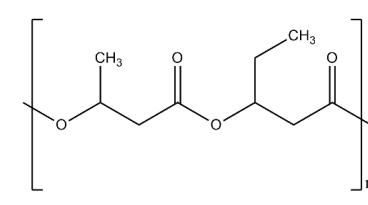

Fig. 1 Structure of the applied polymers: PCL (A), PLA (B), PLGA (C), PLC (D), PHB / HV (E).

Table 1 Optimized solution concentrations of different polymers.

\begin{tabular}{lcc}
\hline Polymer & $\begin{array}{c}\text { Concentration } \\
(\mathbf{w} / \mathbf{V}) \%\end{array}$ & Solvent \\
\hline PCL & 12.0 & dichlormethane:DMF 1:1 \\
PLA & 5.0 & chloroform:DMF 6:1 \\
PHB / HV & 12.0 & chloroform:DMF 4:1 \\
PLC & 10.0 & chloroform:DMF 6:1 \\
PLGA & 6.0 & chloroform:DMF 6:1 \\
\hline
\end{tabular}

foil was applied on the collector and later when using the optimal settings, inert foils were used. Poly(ethyleneterephthalate) (PET), polypropylene (PP) and PLA foil were tested and the PP foil was chosen for further investigation based on the good process handling. The electrospinning of biocompatible polymers on an inert carrier makes it possible to test the potential applicability of scaffolds in an easy to use plate system.

\subsection{Morphology}

Optical microscope and scanning electron microscope (SEM) were used to analyze the structure of the nanofibrous scaffolds and the morphology of the fibers prepared using the optimal solution compositions (Fig. 2, Table 2).

SEM image of the polymers showed that the fibers had random orientation and the diameter of the fibers was submicron sized, thus the electrospinning proved to be satisfactory. Fibers in a submicron range are promising for cell cultivation since this range of fiber diameters is suitable for the biomimetics of the extracellular matrix. The density of the fibers was similar; however, the PHB / HV scaffold consisted of a thick layer of fiber.

\subsection{Surface characteristic}

The scaffolds were hydrophobic, thus low-pressure air plasma surface treatment was carried out to increase the wettability of the samples $[64,65]$. The optimization was achieved to make the samples hydrophilic for the use of cell cultivation. The wettability of the nanofibrous scaffolds was quantified by contact angle measurements to evaluate the effect of plasma treatment (Table 3 ). The samples had high contact angle and hydrophobic characteristic before the plasma treatment. However, the PHB / HV scaffold had better wettability, because the contact angle is affected not only by the surface chemistry but also by the surface roughness $[66,67]$. Based on the SEM images the PHB / HV scaffolds had different fiber density and surface roughness (Fig. 2).

Table 2 Average fiber diameters average and standard deviation (SD) for the scaffolds

\begin{tabular}{lccc}
\hline Polymer & $\begin{array}{c}\text { Polymer } \\
\text { concentration (\%) }\end{array}$ & $\begin{array}{c}\text { Average fiber } \\
\text { diameter (nm) }\end{array}$ & SD (\%) \\
\hline PCL & 12.0 & 655 & $22 \%$ \\
PLA & 5.0 & 763 & $15 \%$ \\
PLGA & 6.0 & 643 & $23 \%$ \\
PLC & 10.0 & 481 & $20 \%$ \\
PHB / HV & 12.0 & 769 & $20 \%$ \\
\hline
\end{tabular}



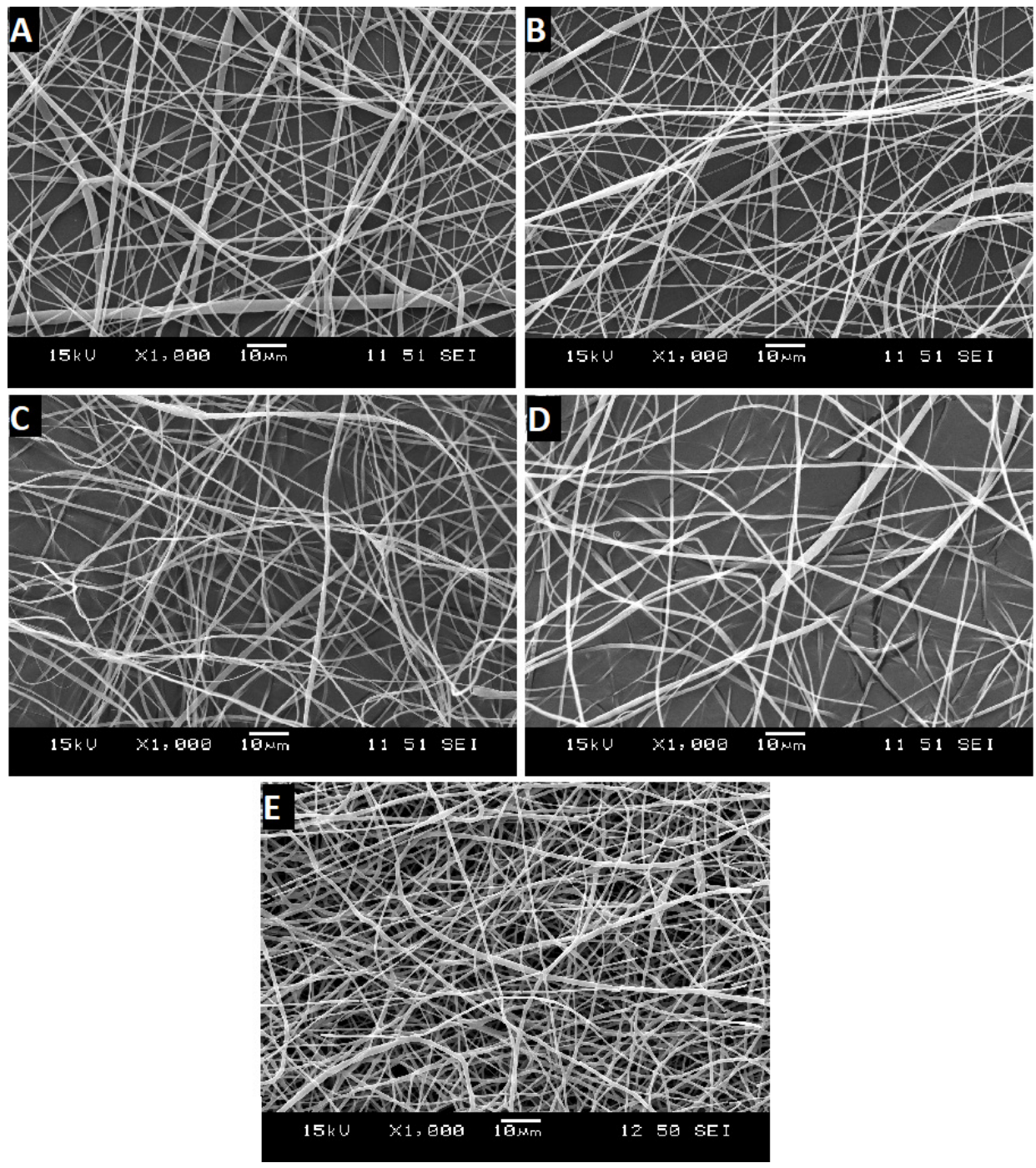

Fig. 2 SEM images of nanofibrous scaffolds: PCL (12.0\%) (A), PLA $5.0 \%$ (B), PLGA $6.0 \%$ (C), PLC $10.0 \%$ (D), PHB / HV $12.0 \%$ (E)

Table 3 Contact angle of distilled water on the scaffold surface before the plasma treatment, right after and 5 days later

\begin{tabular}{lccc}
\hline Polymer & $\begin{array}{c}\text { Before } \\
\text { treatment }\end{array}$ & $\begin{array}{c}\text { After } \\
\text { treatment }\end{array}$ & 5 days later \\
\hline PCL (10 s) & $113^{\circ}$ & $46^{\circ}$ & $46^{\circ}$ \\
PCL (1 min) & & $21^{\circ}$ & $37^{\circ}$ \\
PLA (1 min) & $103^{\circ}$ & $34^{\circ}$ & $59^{\circ}$ \\
PLC (1 min) & $113^{\circ}$ & $56^{\circ}$ & $94^{\circ}$ \\
PLGA (1 min) & $116^{\circ}$ & $46^{\circ}$ & $54^{\circ}$ \\
PHB / HV (1 min $)$ & $85^{\circ}$ & $59^{\circ}$ & $65^{\circ}$ \\
\hline
\end{tabular}

The plasma treatment was successful to decrease the contact angles and to increase the wettability of the scaffolds. By increasing the duration of plasma treatment of the PCL scaffold, the contact angle decreased. The 5 days storage resulted in the increase of the contact angles of the 1 minute plasma treated samples. On the contrary, the contact angle of the 10 seconds plasma treated sample remained the same during the storage. Regarding the stability of wettability, the shorter plasma treatment would be more advantageous, since it polarized mainly the surface of the scaffold and the polymer molecules remained less mobile. However, the 1 minute plasma treatment resulted better wettability after the plasma treatment and after 5 days storage as well. The other polymer scaffolds were, therefore, treated for 1 minute. The surface treatment had a different influence on the electrospun materials since the hydrophobic features of the polymers are different (Table 3).

To understand the effect of plasma treatment, the chemical composition of the surface of the PCL scaffold was examined using X-ray photoelectron spectroscopy on the untreated and the 1 min plasma treated sample (the day after surface treatment). The atomic composition of the 
surface was determined in order to gain information about the differences between the scaffold before and after the modification (Table 4). The surface composition of the scaffold proved to be different from the theoretical value calculated for pure PCL. This can be ascribed to that, the polar, hydrophilic groups face inwards in the fibers as a consequence of the drying process. During the electrospinning the polar solvent first evaporates from the surface of the polymer jet, resulting to direct the groups on the polymer chain toward the remaining solvent and other polymer molecules inside the fibers. The lack of hydrophilic groups on the surface could explain the low oxygen ratio and the large contact angle of the samples.

The binding energy of the atoms was determined and similar energy profiles were detected during the measurement, the intensities of the oxygen atoms were corresponding. As far as the carbon atoms are concerned, the equivalent binding energies were identified on the spectra (Fig. 3).

In Fig. 3 the carbon and oxygen atoms are numbered on the structure of PCL polymer to make the evaluation easier. The $\mathrm{C} 5$ label means the carbon atom right next to the oxygen atom with an ether bond.

As it can be seen in the spectra, the surface treatment had an enormous impact on the scaffold. It has been observed that the untreated samples comprised more hydrocarbon-related carbon atoms than the theoretical ratio. Carbonyl oxygens (O1) found to be in majority compared to ethereal ones in both scaffolds. Although the overall ratio of oxygen atoms increased, their types did not change. The ratio of carbonyl carbon atoms increased, whilst the top layer of hydrocarbons - probably an air-condensed hydrophobic layer - vanished completely after the plasma treatment. The molecule became more polarized and consequently hydrophilic due to the removal of the inwards oriented (due to drying) surface molecules. After the plasma treatment, the polymer scaffolds were wettable because of the presence of newly generated oxygen-containing groups on the surface.

Table 4 Percent composition of $\mathrm{C}$ and $\mathrm{O}$ atoms in the PCL scaffolds: MM-PCL = untreated PCL scaffold, MM-PCL-P1 = plasma treated PCL scaffold

\begin{tabular}{lccc}
\hline \multirow{2}{*}{ Sample name } & \multicolumn{2}{c}{$\begin{array}{c}\text { Chemical } \\
\text { composition }\end{array}$} & \multirow{2}{*}{$\begin{array}{c}\text { O/C atomic } \\
\text { ratio (\%) }\end{array}$} \\
\cline { 2 - 3 } & $\begin{array}{c}\text { Oxigen } \\
\mathbf{( \% )}\end{array}$ & $\begin{array}{c}\text { Carbon } \\
\mathbf{( \% )}\end{array}$ & \\
\hline PCL theoretical & 25.0 & 75.0 & 33.3 \\
MM-PCL & 18.6 & 81.4 & 22.9 \\
MM-PCL-P1 & 21.5 & 78.5 & 27.4 \\
\hline
\end{tabular}
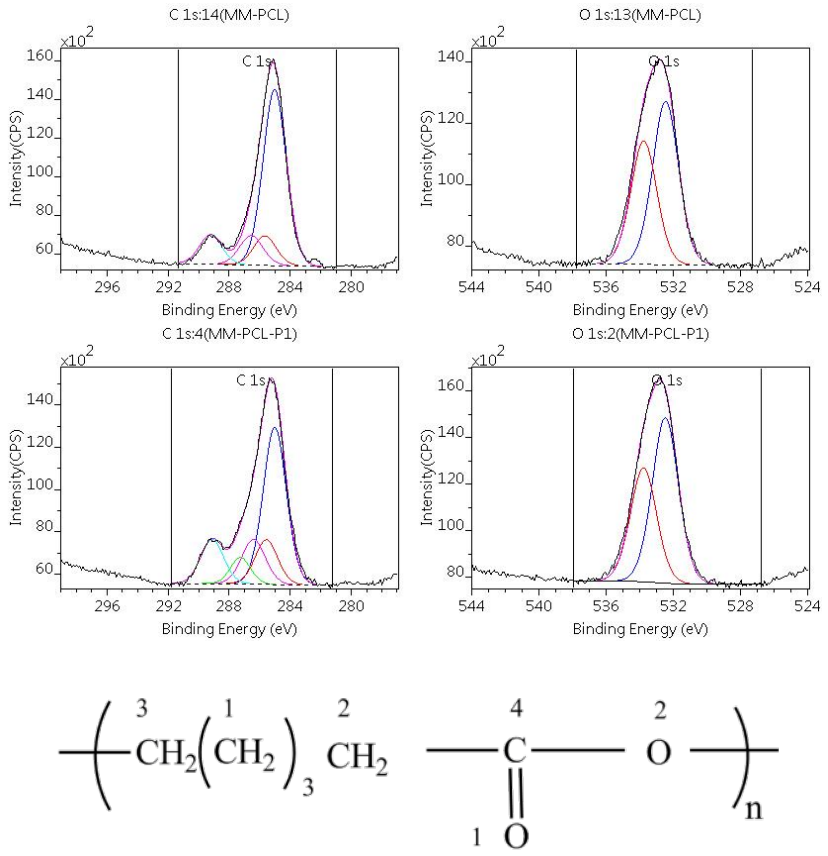

Fig. 3 XPS spectra according to the carbon and oxygen atoms: MM-PCL = untreated PCL scaffold, MM-PCL-P1 = plasma treated PCL scaffold and the structural formula of PCL with the atoms labeled

Table 5 Atomic percent composition according to all the atoms in the polymer: $\mathrm{MM}-\mathrm{PCL}=$ untreated PCL scaffold, MM-PCL-P1 = plasma treated PCL scaffold

\begin{tabular}{lccccccc}
\hline & \multicolumn{7}{c}{ Atomic percent (\%) } \\
\cline { 2 - 8 } Sample name & O1 & O2 & C1 & C2 & C3 & C4 & C5 \\
\hline Theoretical & 12.5 & 12.5 & 37.5 & 12.5 & 12.5 & 12.5 & - \\
MM-PCL & 10.6 & 8.0 & 54.2 & 8.9 & 9.3 & 8.9 & - \\
MM-PCL-P1 & 12.8 & 8.8 & 39.4 & 11.0 & 11.4 & 10.9 & 5.7 \\
\hline
\end{tabular}

\section{Conclusion}

Nanofibrous scaffolds were prepared from biodegradable polymers and copolymers by applying the electrospinning technique. The polymer concentrations, the solution compositions, and the electrospinning parameters were optimized to achieve adequate fibers in a submicron range. The electrospun fibers of PCL, PLA, PHB / HV, PLC, and PLGA polymer solutions were deposited on an inert PP carrier and was placed in a cell cultivation plate to obtain an easy to use the system for the comparison of the applicability of scaffolds. The prepared scaffolds were characterized based on morphology, wettability, and surface chemical composition. The PCL scaffolds comprised more hydrocarbon-related carbon atoms than the theoretical ratio and the samples were quite hydrophobic. The drying induced orientation of the polar groups on the polymer chain presumably the reason for the deviation from the theoretical value. The surface treatment 
of the scaffolds was necessary to increase the hydrophilicity of the scaffolds. Based on the optimization a 1-minute plasma treatment was applied on the samples. The total ratio of oxygen atoms had increased on the surface of the plasma treated sample. The use of plasma treatment was successful to increase the hydrophilicity because of the removal of the oriented surface molecules and the newly generated oxygen-containing groups on the surface. The molecules on the surface became more polarized and as a consequence, the scaffold had good wettability.

\section{References}

[1] He, J.-H., Wan, Y.-Q., Yu, J.-Y. "Scaling law in electrospinning: relationship between electric current and solution flow rate", Polymer, 46(8), pp. 2799-2801, 2005. https://doi.org/10.1016/j.polymer.2005.01.065

[2] He, W., Horn, S. W., Hussain, M. D. "Improved bioavailability of orally administered mifepristone from PLGA nanoparticles", International Journal of Pharmaceutics, 334(1-2), pp. 173-178, 2007. https://doi.org/10.1016/j.ijpharm.2006.10.025

[3] Gopal, R., Kaur, S., Ma, Z., Chan, C., Ramakrishna, S., Matsuura, T. "Electrospun nanofibrous filtration membrane", Journal of Membrane Science, 281(1-2), pp. 581-586, 2006. https://doi.org/10.1016/j.memsci.2006.04.026

[4] Aussawasathien, D., Teerawattananon, C., Vongachariya, A. "Separation of micron to sub-micron particles from water: Electrospun nylon-6 nanofibrous membranes as pre-filters", Journal of Membrane Science, 315(1-2), pp. 11-19, 2008. https://doi.org/10.1016/j.memsci.2008.01.049

[5] Lee, S., Obendorf, S. K. "Use of Electrospun Nanofiber Web for Protective Textile Materials as Barriers to Liquid Penetration", Textile Research Journal, 77(9), pp. 696-702, 2007. https://doi.org/10.1177/0040517507080284

[6] Chung, S. E., Park, C. H. "Manufacture of shape memory polyurethane electrospun web", Patent KR20100048661A, 2010

[7] Lee, S., Obendorf, S. K. "Developing protective textile materials as barriers to liquid penetration using melt-electrospinning", Journal of Applied Polymer Science, 102(4), pp. 3430-3437, 2006. https://doi.org/10.1002/app.24258

[8] Gorji, M., Jeddi, A. A. A., Gharehaghaji, A. A. "Fabrication and characterization of polyurethane electrospun nanofiber membranes for protective clothing applications", Journal of Applied Polymer Science, 125(5), pp. 4135-4141, 2012.

https://doi.org/10.1002/app.36611

[9] Rojas, R., Pinto, N. J. "Using Electrospinning for the Fabrication of Rapid Response Gas Sensors Based on Conducting Polymer Nanowires", IEEE Sensors Journal, 8(6), pp. 951-953, 2008. https://doi.org/10.1109/JSEN.2008.923932

[10] Kowalczyk, T., Nowicka, A., Elbaum, D., Kowalewski, T. A. "Electrospinning of Bovine Serum Albumin. Optimization and the Use for Production of Biosensors", Biomacromolecules, 9(7), pp. 2087-2090, 2008.

https://doi.org/10.1021/bm800421s

\section{Acknowledgment}

This project was supported by OTKA grant KH 124541, PD 116122, PD-121051, GINOP-2.1.1-15-2015-00541, ÚNKP-17-4-I \& ÚNKP-17-4-II New National Excellence Program of the Ministry of Human Capacities, and Ph.D. scholarship from the Gedeon Richter's Talentum Foundation. This work was supported by the National Research, Development and Innovation Fund of Hungary in the frame of FIEK_16-1-2016-0007 (Higher Education and Industrial Cooperation Center) project.

[11] Zahedi, P., Rezaeian, I., Ranaei-Siadat, S.-O., Jafari, S.-H., Supaphol, P. "A review on wound dressings with an emphasis on electrospun nanofibrous polymeric bandages", Polymers for Advanced Technologies, 21(2), pp. 77-95, 2010.

https://doi.org/10.1002/pat.1625

[12] Khil, M.-S., Cha, D.-I., Kim, H.-Y., Kim, I.-S., Bhattarai, N. "Electrospun nanofibrous polyurethane membrane as wound dressing", Journal of Biomedical Materials Research, 67B(2), pp. 675-679, 2003.

https://doi.org/10.1002/jbm.b.10058

[13] Rieger, K. A., Birch, N. P., Schiffman, J. D. "Designing electrospun nanofiber mats to promote wound healing - a review", Journal of Materials Chemistry B, 1(36), pp. 4531-4541, 2013. https://doi.org/10.1039/C3TB20795A

[14] Pillay, V., Dott, C., Choonara, Y. E., Tyagi, C., Tomar, L., Kumar, P., du Toit, L. C., Ndesendo, V. M. K. "A Review of the Effect of Processing Variables on the Fabrication of Electrospun Nanofibers for Drug Delivery Applications", Journal of Nanomaterials, 2013, pp. 1-22, 2013. https://doi.org/10.1155/2013/789289

[15] Sill, T. J., von Recum, H. A. "Electrospinning: Applications in drug delivery and tissue engineering", Biomaterials, 29(13), pp. 1989-2006, 2008. https://doi.org/10.1016/j.biomaterials.2008.01.011

[16] Sóti, P. L., Nagy, Z. K., Serneels, G., Vajna, B., Farkas, A., Van der Gucht, F., Fekete, P., Vigh, T., Wagner, I., Balogh, A., Pataki, H., Mező, G., Marosi, G. "Preparation and comparison of spray dried and electrospun bioresorbable drug delivery systems", European Polymer Journal, 68, pp. 671-679, 2015. https://doi.org/10.1016/j.eurpolymj.2015.03.035

[17] Farkas, B., Balogh, A., Farkas, A., Domokos, A., Borbás, E., Marosi, G., Nagy, Z. K. "Medicated Straws Based on Electrospun Solid Dispersions", Periodica Polytechnica Chemical Engineering, 62(3), pp. 310-316, 2018. https://doi.org/10.3311/PPch.11931

[18] Lu, T., Chen, X., Shi, Q., Wang, Y., Zhang, P., Jing, X. "The immobilization of proteins on biodegradable fibers via biotin-streptavidin bridges", Acta Biomaterialia, 4(6), pp. 1770-1777, 2008. https://doi.org/10.1016/j.actbio.2008.05.006 
[19] Sóti, P. L., Weiser, D., Vigh, T., Nagy, Z. K., Poppe, L., Marosi, G. "Electrospun polylactic acid and polyvinyl alcohol fibers as efficient and stable nanomaterials for immobilization of lipases", Bioprocess and Biosystems Engineering, 39(3), pp. 449-459, 2016. https://doi.org/10.1007/s00449-015-1528-y

[20] Pham, Q. P., Sharma, U., Mikos, A. G. "Electrospinning of Polymeric Nanofibers for Tissue Engineering Applications: A Review", Tissue Engineering, 12(5), pp. 1197-1211, 2006. https://doi.org/10.1089/ten.2006.12.1197

[21] Yoo, H. S., Kim, T. G., Park, T. G. "Surface-functionalized electrospun nanofibers for tissue engineering and drug delivery", Advanced Drug Delivery Reviews, 61(12), pp. 1033-1042, 2009. https://doi.org/10.1016/j.addr.2009.07.007

[22] Suzuki, A., Mikuni, T., Hasegawa, T. "Nylon 66 nanofibers prepared by $\mathrm{CO} 2$ laser supersonic drawing", Journal of Applied Polymer Science, 131(6), pp. 40015(1-11), 2014. https://doi.org/10.1002/app.40015

[23] Suzuki, A., Arino, K. "Polypropylene nanofiber sheets prepared by $\mathrm{CO}_{2}$ laser supersonic multi-drawing", European Polymer Journal, 48(7), pp. 1169-1176, 2012. https://doi.org/10.1016/j.eurpolymj.2012.04.003

[24] Wang, S., Zhang, Y., Wang, W., Li, G., Ma, X., Li, X., Zhang, Z., Qian, Y. "Template-assisted synthesis of porous molybdenum dioxide nanofibers and nanospheres by redox etching method", Journal of Crystal Growth, 290(1), pp. 96-102, 2006. https://doi.org/10.1016/j.jcrysgro.2005.10.149

[25] Tao, S. L., Desai, T. A. "Aligned Arrays of Biodegradable Poly( $\varepsilon-$ caprolactone) Nanowires and Nanofibers by Template Synthesis", Nano Letters, 7(6), pp. 1463-1468, 2007. https://doi.org/10.1021/n10700346

[26] Smith, L. A., Ma, P. X. "Nano-fibrous scaffolds for tissue engineering", Colloids and Surfaces B: Biointerfaces, 39(3), pp. 125-131, 2004.

https://doi.org/10.1016/j.colsurfb.2003.12.004

[27] Ichimori, T., Mizuma, K., Uchida, T., Yamazaki, S., Kimura, K. "Morphological diversity and nanofiber networks of poly(p-oxybenzoyl) generated by phase separation during copolymerization", Journal of Applied Polymer Science, 128(2), pp. 1282-1290, 2013. https://doi.org/10.1002/app.38554

[28] Shao, J., Chen, C., Wang, Y., Chen, X., Du, C. "Early stage evolution of structure and nanoscale property of nanofibers in thermally induced phase separation process", Reactive and Functional Polymers, 72(10), pp. 765-772, 2012.

https://doi.org/10.1016/j.reactfunctpolym.2012.07.011

[29] Nagy, Z. K., Balogh, A., Drávavölgyi, G., Ferguson, J., Pataki, H., Vajna, B., Marosi, G. "Solvent-Free Melt Electrospinning for Preparation of Fast Dissolving Drug Delivery System and Comparison with Solvent-Based Electrospun and Melt Extruded Systems", Journal of Pharmaceutical Sciences, 102(2), pp. 508517, 2013.

https://doi.org/10.1002/jps.23374
[30] Wunner, F. M., Maartens, J., Bas, O., Gottschalk, K., De-JuanPardo, E. M., Hutmacher, D. W. "Electrospinning writing with molten poly ( $\varepsilon$-caprolactone) from different directions - Examining the effects of gravity", Materials Letters, 216, pp. 114-118, 2018. https://doi.org/10.1016/j.matlet.2017.12.079

[31] Feltz, K. P., Growney Kalaf, E. A., Chen, C., Martin, R. S., Sell, S. A. "A review of electrospinning manipulation techniques to direct fiber deposition and maximize pore size", Electrospinning, 1(1), pp. 46-61, 2017. https://doi.org/10.1515/esp-2017-0002

[32] Yang, G.-Z., Li, J.-J., Yu, D.-G., He, M.-F., Yang, J.-H., Williams, G. R. "Nanosized sustained-release drug depots fabricated using modified tri-axial electrospinning", Acta Biomaterialia, 53, pp. 233-241, 2017. https://doi.org/10.1016/j.actbio.2017.01.069

[33] Kulkarni, A., Bambole, V. A., Mahanwar, P. A. "Electrospinning of Polymers, Their Modeling and Applications", Polymer-Plastics Technology and Engineering, 49(5), pp. 427-441, 2013. https://doi.org/10.1080/03602550903414019

[34] Hsu, C.-M., Shivkumar, S. "N,N-Dimethylformamide Additions to the Solution for the Electrospinning of Poly( $\varepsilon$-caprolactone) Nanofibers", Macromolecular Materials and Engineering, 289(4), pp. 334-340, 2004.

https://doi.org/10.1002/mame.200300224

[35] Powell, H. M., Boyce, S. T. "Fiber density of electrospun gelatin scaffolds regulates morphogenesis of dermal-epidermal skin substitutes", Journal of Biomedical Materials Research Part A, 84A(4), pp. 1078-1086, 2008. https://doi.org/10.1002/jbm.a.31498

[36] Smith, M. J., White, K. L., Smith, D. C., Bowlin, G. L. "In vitro evaluations of innate and acquired immune responses to electrospun polydioxanone-elastin blends", Biomaterials, 30(2), pp. 149-159, 2009. https://doi.org/10.1016/j.biomaterials.2008.09.019

[37] Liu, W., Thomopoulos, S., Xia, Y. "Electrospun Nanofibers for Regenerative Medicine", Advanced Healthcare Materials, 1(1), pp. 10-25, 2012. https://doi.org/10.1002/adhm.201100021

[38] Zong, X., Bien, H., Chung, C.-Y., Yin, L., Fang, D., Hsiao, B. S., Chu, B., Entcheva, E. "Electrospun fine-textured scaffolds for heart tissue constructs", Biomaterials, 26(26), pp. 5330-5338, 2005. https://doi.org/10.1016/j.biomaterials.2005.01.052

[39] Bini, T. B., Gao, S., Wang, S., Ramakrishna, S. "Poly (1-lactideco-glycolide) biodegradable microfibers and electrospun nanofibers for nerve tissue engineering: an in vitro study", Journal of Materials Science, 41(19), pp. 6453-6459, 2006. https://doi.org/10.1007/s10853-006-0714-3

[40] Ghasemi-Mobarakeh, L., Prabhakaran, M. P., Morshed, M., NasrEsfahani, M.-H., Ramakrishna, S. "Electrospun poly ( $\varepsilon$-caprolactone)/gelatin nanofibrous scaffolds for nerve tissue engineering", Biomaterials, 29(34), pp. 4532-4539, 2008. https://doi.org/10.1016/j.biomaterials.2008.08.007 
[41] Jha, B. S., Colello, R. J., Bowman, J. R., Sell, S. A., Lee, K. D., Bigbee, J. W., Bowlin, G. L., Chow, W. N., Mathern, B. E., Simpson, D. G. "Two pole air gap electrospinning: Fabrication of highly aligned, three-dimensional scaffolds for nerve reconstruction", Acta Biomaterialia, 7(1), pp. 203-215, 2011.

https://doi.org/10.1016/j.actbio.2010.08.004

[42] Browning, M. B., Dempsey, D., Guiza, V., Becerra, S., Rivera, J., Russell, B., Höök, M., Clubb, F., Miller, M., Fossum, T., Dong, J. F., Bergeron, A. L., Hahn, M., Cosgriff-Hernandez, E. "Multilayer vascular grafts based on collagen-mimetic proteins", Acta Biomaterialia, 8(3), pp. 1010-1021, 2012.

https://doi.org/10.1016/j.actbio.2011.11.015

[43] Hasan, A., Memic, A., Annabi, N., Hossain, M., Paul, A., Dokmeci, M. R., Dehghani, F., Khademhosseini, A. "Electrospun scaffolds for tissue engineering of vascular grafts", Acta Biomaterialia, 10(1), pp. 11-25, 2014.

https://doi.org/10.1016/j.actbio.2013.08.022

[44] McKenna, K. A., Hinds, M. T., Sarao, R. C., Wu, P.-C., Maslen, C. L., Glanville, R. W., Babcock, D., Gregory, K. W. "Mechanical property characterization of electrospun recombinant human tropoelastin for vascular graft biomaterials", Acta Biomaterialia, 8(1), pp. 225-233, 2012.

https://doi.org/10.1016/j.actbio.2011.08.001

[45] Sisson, K., Zhang, C., Farach-Carson, M. C., Chase, D. B., Rabolt, J. F. "Fiber diameters control osteoblastic cell migration and differentiation in electrospun gelatin", Journal of Biomedical Materials Research Part A, 94A(4), pp. 1312-1320, 2010.

https://doi.org/10.1002/jbm.a.32756

[46] Francis, M. P., Moghaddam-White, Y. M., Sachs, P. C., Beckman, M. J., Chen, S. M., Bowlin, G. L., Elmore, L. W., Holt, S. E. "Modeling early stage bone regeneration with biomimetic electrospun fibrinogen nanofibers and adipose-derived mesenchymal stem cells", Electrospinning, 1(1), pp. 10-19, 2016. https://doi.org/10.1515/esp-2016-0002

[47] Almarza, A. J., Athanasiou, K. A. "Design Characteristics for the Tissue Engineering of Cartilaginous Tissues", Annals of Biomedical Engineering, 32(1), pp. 2-17, 2004.

https://doi.org/10.1023/B:ABME.0000007786.37957.65

[48] Barnes, C. P., Pemble IV, C. W., Brand, D. D., Simpson, D. G., Bowlin, G. L. "Cross-Linking Electrospun Type II Collagen Tissue Engineering Scaffolds with Carbodiimide in Ethanol", Tissue Engineering, 13(7), pp. 1593-1605, 2007.

https://doi.org/10.1089/ten.2006.0292

[49] Alessandrino, A., Marelli, B., Arosio, C., Fare, S., Tanzi, M. C., Freddi, G. "Electrospun Silk Fibroin Mats for Tissue Engineering", Engineering in Life Sciences, 8(3), pp. 219-225, 2008. https://doi.org/10.1002/elsc.200700067

[50] Bashur, C. A., Dahlgren, L. A., Goldstein, A. S. "Effect of fiber diameter and orientation on fibroblast morphology and proliferation on electrospun poly (D, L-lactic-co-glycolic acid) meshes", Biomaterials, 27(33), pp. 5681-5688, 2006. https://doi.org/10.1016/j.biomaterials.2006.07.005
[51] Cho, S. J., Jung, S. M., Kang, M., Shin, H. S., Youk, J. H. "Preparation of hydrophilic PCL nanofiber scaffolds via electrospinning of PCL/PVP- $b$-PCL block copolymers for enhanced cell biocompatibility", Polymer, 69, pp. 95-102, 2015.

https://doi.org/10.1016/j.polymer.2015.05.037

[52] Yang, F., Murugan, R., Wang, S., Ramakrishna, S. "Electrospinning of nano/micro scale poly(L-lactic acid) aligned fibers and their potential in neural tissue engineering", Biomaterials, 26(15), pp. 2603-2610, 2005.

https://doi.org/10.1016/j.biomaterials.2004.06.051

[53] Hwang, T. I., Maharjan, B., Tiwari, A. P., Lee, S., Joshi, M. K., Park, C. H., Kim, C. S. "Facile fabrication of spongy nanofibrous scaffold for tissue engineering applications", Materials Letters, 219, pp. 119-122, 2018. https://doi.org/10.1016/j.matlet.2018.02.040

[54] Liu, X., Baldursdottir, S. G., Aho, J., Qu, H., Christensen, L. P., Rantanen, J., Yang, M. "Electrospinnability of Poly Lacticco-glycolic Acid (PLGA): the Role of Solvent Type and Solvent Composition", Pharmaceutical Research, 34(4), pp. 738-749, 2017. https://doi.org/10.1007/s11095-017-2100-Z

[55] Zhao, W., Li, J., Jin, K., Liu, W., Qiu, X., Li, C. "Fabrication of functional PLGA-based electrospun scaffolds and their applications in biomedical engineering", Materials Science and Engineering: C, 59, pp. 1181-1194, 2016. https://doi.org/10.1016/j.msec.2015.11.026

[56] Stankus, J. J., Guan, J., Wagner, W. R. "Fabrication of biodegradable elastomeric scaffolds with sub-micron morphologies", Journal of Biomedical Materials Research Part A, 70A(4), pp. 603-614, 2004.

https://doi.org/10.1002/jbm.a.30122

[57] Alessandrino, A., Marelli, B., Arosio, C., Fare, S., Tanzi, M. C., Freddi, G. "Electrospun Silk Fibroin Mats for Tissue Engineering", Engineering in Life Sciences, 8(3), pp. 219-225, 2008. https://doi.org/10.1002/elsc.200700067

[58] Chan, C. K., Liao, S., Li, B., Lareu, R. R., Larrick, J. W., Ramakrishna, S., Raghunath, M. "Early adhesive behaviour of bone-marrow-derived mesenchymal stem cells on collagen electrospun fibers", Biomedical Materials, 4(3), pp. 1-10, 2009. https://doi.org/10.1088/1748-6041/4/3/035006

[59] Hall Barrientos, I. J., Paladino, E., Szabó, P., Brozio, S., Hall, P. J., Oseghale, C. I., Passarelli, M. K., Moug, S. J., Black, R. A., Wilson, C. G., Zelkó, R., Lamprou, D. A. "Electrospun collagen-based nanofibres: A sustainable material for improved antibiotic utilisation in tissue engineering applications", International Journal of Pharmaceutics, 531(1), pp. 67-79, 2017. https://doi.org/10.1016/j.ijpharm.2017.08.071

[60] Um, I. C., Fang, D., Hsiao, B. S., Okamoto, A., Chu, B. "Electro-Spinning and Electro-Blowing of Hyaluronic Acid", Biomacromolecules, 5(4), pp. 1428-1436, 2004. https://doi.org/10.1021/bm034539b

[61] Ma, Z., Kotaki, M., Ramakrishna, S. "Electrospun cellulose nanofiber as affinity membrane", Journal of Membrane Science, 265(1-2), pp. 115-123, 2005.

https://doi.org/10.1016/j.memsci.2005.04.044 
[62] Chen, Z., Mo, X., Qing, F. "Electrospinning of collagen-chitosan complex", Materials Letters, 61(16), pp. 3490-3494, 2007. https://doi.org/10.1016/j.matlet.2006.11.104

[63] Khajavi, R., Abbasipour, M., Bahador, A. "Electrospun biodegradable nanofibers scaffolds for bone tissue engineering", Journal of Applied Polymer Science, 133(3), pp. 1-19, 2016. https://doi.org/10.1002/app.42883

[64] Janvikul, W., Uppanan, P., Thavornyutikarn, B., Kosorn W., Kaewkong P. "Effects of Surface Topography, Hydrophilicity and Chemistry of Surface-treated PCL Scaffolds on Chondrocyte Infiltration and ECM Production", Procedia Engineering, 59, pp. 158-165, 2013.

https://doi.org/10.1016/j.proeng.2013.05.106
[65] Kosorn, W., Thavornyutikarn, B., Janvikul, W. "Effects of Surface Treatments of Polycaprolactone Scaffolds on their Properties", Advanced Materials Research, 747, pp. 178-181, 2013. https://doi.org/10.4028/www.scientific.net/AMR.747.178

[66] Marmur, A. "Soft contact: measurement and interpretation of contact angles", Soft Matter, 2(1), pp. 12-17, 2006 https://doi.org/10.1039/B514811C

[67] Románszki, L., Mohos, M., Telegdi, J., Keresztes, Z., Nyikos, L. "A comparison of contact angle measurement results obtained on bare, treated, and coated alloy samples by both dynamic sessile drop and Wilhelmy method", Periodica Polytechnica Chemical Engineering, 58(Supplement), pp. 53-59, 2014. https://doi.org/10.3311/PPch.7188 